\title{
Response of Potato Cultivars to Phosphate Fertilization in Tropical Soils with Different Phosphorus Availabilities
}

\author{
Adalton M. Fernandes ${ }^{1} \cdot$ Rogério P. Soratto $^{2}$
}

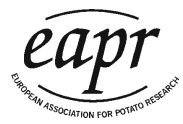

Received: 4 March 2016 / Accepted: 22 September 2016 /

Published online: 24 October 2016

(C) European Association for Potato Research 2016

\begin{abstract}
Potato cultivars have different strategies for dealing with phosphorus (P) deficiency in soil, and their response to $\mathrm{P}$ fertilization may vary because of differences in soil $\mathrm{P}$ availability. This study was performed to evaluate the effect of $\mathrm{P}$ fertilization rates $\left(0,125,250,500\right.$, and $1000 \mathrm{~kg} \mathrm{P}_{2} \mathrm{O}_{5}$ per hectare) on the $\mathrm{P}$ uptake, fertilizer $\mathrm{P}$ recovery, tuber yield, and applied $\mathrm{P}$ use efficiency of five potato cultivars (Agata, Asterix, Atlantic, Markies, and Mondial) grown in Oxisols with low, medium, and high $\mathrm{P}$ availability in southeastern Brazil. The tuber yield of all potato cultivars increased similarly with increase in P fertilizer application up to rates of 500,250 , and $125 \mathrm{~kg}$ $\mathrm{P}_{2} \mathrm{O}_{5}$ per hectare in the soils with low, medium, and high $\mathrm{P}$ availability respectively. This increase was found despite the leaf $\mathrm{P}$ concentrations being lower than the deficiency limit of $2.5 \mathrm{~g} \mathrm{~kg}^{-1}$ only in the soil with low P availability in the absence of $\mathrm{P}$ fertilizer application. The application of phosphate fertilizer in the planting furrow resulted in a greater increase in the leaf $\mathrm{P}$ concentration, plant growth, $\mathrm{P}$ uptake, number of tubers per plant, tuber mean weight, tuber yield, and $\mathrm{P}$ removal of the potato crop grown in the soil with low $\mathrm{P}$ availability compared with soils with high $\mathrm{P}$ availability. In soil with high $\mathrm{P}$ availability, $\mathrm{P}$ application rates higher than $125 \mathrm{~kg} \mathrm{P}_{2} \mathrm{O}_{5}$ per hectare did not increase the number, size, and yield of tubers. The cultivar Mondial had the highest tuber yield, fertilizer $\mathrm{P}$ recovery, and applied $\mathrm{P}$ use efficiency, especially at the lower $\mathrm{P}$ application rates, but at a specific initial $\mathrm{P}$ availability, all cultivars responded to the same $\mathrm{P}$ application rate. The results indicate that phosphate fertilizer recommendations should be adjusted on the basis of soil $\mathrm{P}$ availability, and that it is not necessary to use different criteria to evaluate the P-nutritional status for individual potato cultivars.
\end{abstract}

Rogério P. Soratto

soratto@fca.unesp.br

1 Center for Tropical Roots and Starches (CERAT), São Paulo State University (UNESP),

P.O. Box 237, 18610-307 Botucatu, SP, Brazil

2 Department of Crop Science, College of Agricultural Sciences, São Paulo State University (UNESP), P.O. Box 237, 18610-307 Botucatu, SP, Brazil 
Keywords Applied phosphorus use efficiency · Fertilizer phosphorus recovery Phosphorus removal $\cdot$ Phosphorus uptake $\cdot$ Solanum tuberosum . Tuber yield

\section{Introduction}

Phosphorus (P) deficiency is one of the most widespread nutrient constraints limiting the yield of crops in the tropics. This occurs because a large proportion of the $\mathrm{P}$ is bound to soil constituents, forming complexes that have limited bioavailability, thus making the P unavailable for plant uptake (Sánches and Salinas 1981; Valladares et al. 2003).

Potato (Solanum tuberosum L.), a major global food crop, is increasingly grown in tropical and developing countries (FAOSTAT 2016). Potato has a high nutrient demand (Fernandes et al. 2011b) because of its short development cycle and high yield and has low P-uptake efficiency, especially when grown in soils deficient in P (Pursglove and Sanders 1981; Dechassa et al. 2003; Hopkins et al. 2014; Thornton et al. 2014). Pdeficient potato plants typically exhibit late maturity and reduced growth, yield, and quality of the tubers compared with plants adequately supplied with P (Fontes et al. 1997; Freeman et al. 1998; Alvarez-Sánchez et al. 1999; Rosen and Bierman 2008; Sandaña and Kalazich 2015; Soratto et al. 2015; Fernandes and Soratto 2016).

An adequate $\mathrm{P}$ supply for potato crops is fundamental for increasing the number of tubers per plant and the size of the tubers (Freeman et al. 1998; Rosen and Bierman 2008; Fernandes and Soratto 2016), whereas P fertilization provides the highest yield response of potato crops on soils with low and medium levels of available P (Boock and Freire 1960; Freeman et al. 1998; Alvarez-Sánchez et al. 1999; Rosen and Bierman 2008; Rosen et al. 2014; Fernandes and Soratto 2016). Consequently, high rates of P fertilizer application are used in the potato planting furrow to increase the P availability in the soil (Fontes et al. 1997; Rosen and Bierman 2008; Fernandes and Soratto 2012; Luz et al. 2013; Hopkins et al. 2014; Rosen et al. 2014).

In Brazil, some studies have suggested only a slight response of the potato crop to $\mathrm{P}$ fertilization rates greater than $320-400 \mathrm{~kg} \mathrm{P}_{2} \mathrm{O}_{5}$ per hectare in Oxisols with both low $\mathrm{P}$ availability (Boock and Freire 1960; Fontes et al. 1997; Fernandes and Soratto 2016) and high P availability (Boock and Freire 1960; Luz et al. 2013). However, because potato is a high-value crop, it is common for farmers to use very high $\mathrm{P}$ rates (more than $600 \mathrm{~kg} \mathrm{P}_{2} \mathrm{O}_{5}$ per hectare), even in soils with high $\mathrm{P}$ availability (Sangoi and Kruse 1994; Fernandes et al. 2011b), and this has become increasingly common in cultivated areas. Even under these conditions, the total $\mathrm{P}$ taken up by various potato cultivars remains between 15.2 and $18 \mathrm{~kg} \mathrm{ha}^{-1}$; these quantities represent less than $6.5 \%$ of the $\mathrm{P}$ applied through fertilization (Yorinori 2003; Fernandes et al. 2011b). These results indicate that it may be possible to apply $\mathrm{P}$ at lower rates in soils with high $\mathrm{P}$ availability without compromising tuber yield. Furthermore, the misconception of "if some is good, more is better" can increase crop production costs and cause environmental problems (Barben et al. 2010; Luz et al. 2013; Ruark et al. 2014), and the availability of sources of P fertilizers will likely become limited, at least in the long term (Hopkins et al. 2014; Thornton et al. 2014).

The potato cultivars Agata, Asterix, Atlantic, Markies, and Mondial represent more than $80 \%$ of all potatoes grown in Brazil (ABBA 2010). Greenhouse studies with these 
cultivars revealed differences in their response to $\mathrm{P}$ with respect to tuber yield (Soratto et al. 2015) and strategies for coping with $P$ deficiency in nutrient solutions (Fernandes et al. 2014). The response of potato to $P$ fertilizer may vary depending on the soil conditions and the cultivar, among other factors (Rosen et al. 2014; Sandaña and Kalazich 2015), and according to Rosen et al. (2014), optimization of P management for potato should be based on regional research results. However, there are no studies in southeastern Brazilian field production environments comparing the responses of these cultivars to $\mathrm{P}$ applied at different rates to soils with different $\mathrm{P}$ availabilities.

This study was undertaken to evaluate the effect of $\mathrm{P}$ fertilization rates on the $\mathrm{P}$ uptake, fertilizer P recovery (FPR), tuber yield, and applied P use efficiency (APUE) of five potato cultivars grown in tropical soils with low, medium, and high $\mathrm{P}$ availability.

\section{Materials and Methods}

\section{Site Description}

Field experiments were conducted in three potato production farms located in São Paulo State, southeastern Brazil. The experiments were located near Avaré ( $48^{\circ} 47^{\prime} \mathrm{W}$, $23^{\circ} 02^{\prime} \mathrm{S}$ and $744 \mathrm{~m}$ above sea level), Itaí $\left(49^{\circ} 01^{\prime} \mathrm{W}, 23^{\circ} 28^{\prime} \mathrm{S}\right.$ and 649 above seal level), and Cerqueira César (49 $12^{\prime} \mathrm{W}, 2^{\circ} 07^{\prime} \mathrm{S}$ and 737 above sea level), which had low, medium, and high $P$ availability respectively (van Raij et al. 1997). The soil in the three experimental areas was classified as a clayey Oxisol. The previous crops were grass pasture (Urochloa decumbens Stapf.) at Avaré, soybean [Glycine max (L.) Merr.] at Itaí, and rice (Oryza sativa L.) at Cerqueira César. Soil samples (0- to 20-cm depth) were collected from each area immediately before planting to determine the chemical characteristics according to van Raij et al. (2001) (Table 1).

The region has a Cwa climate (tropical, with a dry winter and a hot, rainy summer), according to the Köppen classification system. Daily rainfall, irrigation, and temperatures were measured during the experimental period (Fig. 1).

\section{Experimental Design and Treatments}

In all experiments, the experimental design was a randomized complete block with a $5 \times 5$ factorial scheme and four replications. The treatments consisted of five potato cultivars (Agata, Asterix, Atlantic, Markies, and Mondial) and five $\mathrm{P}$ fertilization rates $\left(0,125,250,500\right.$, and $1000 \mathrm{~kg} \mathrm{P}_{2} \mathrm{O}_{5}$ per hectare, equivalent to $0,55.5,111,222$, and $444 \mathrm{~kg} \mathrm{P}$ per hectare respectively) applied in the planting furrow as triple superphosphate $\left(45 \% \mathrm{P}_{2} \mathrm{O}_{5}\right)$. The plots $(4 \mathrm{~m} \times 5 \mathrm{~m})$ comprised five 5 -m-long rows with a $0.80-\mathrm{m}$ row spacing. Only the three central rows were used for the experimental measurements; the $0.5 \mathrm{~m}$ at the end of each row and the two outer rows of each plot were disregarded.

\section{Crop Management}

Each farmer followed his own management plan for the potato crop cycle and was responsible for all activities associated with soil tillage, furrow treatment, irrigation, hilling, haulm killing, and the management of pests, weeds, and diseases. 
Table 1 Soil chemical and textural characteristics of the experimental areas measured before potato planting

\begin{tabular}{|c|c|c|c|}
\hline \multirow[t]{2}{*}{ Soil characteristic } & \multicolumn{3}{|c|}{ Soil $\mathrm{P}$ availability } \\
\hline & Low & Medium & High \\
\hline $\mathrm{pH}\left(1: 2.5 \mathrm{soil} / \mathrm{CaCl}_{2}\right.$ suspension $\left.0.01 \mathrm{~mol} \mathrm{l}^{-1}\right)$ & 5.7 & 4.8 & 4.8 \\
\hline Soil organic matter $\left(\mathrm{g} \mathrm{dm}^{-3}\right)$ & 47.6 & 26.7 & 27.8 \\
\hline $\mathrm{P}_{\text {resin-extractable }}\left(\mathrm{mg} \mathrm{dm}^{-3}\right)$ & 14 & 36 & 70 \\
\hline $\mathrm{K}\left(\mathrm{mmol}_{\mathrm{c}} \mathrm{dm}^{-3}\right)$ & 2.3 & 2.3 & 3.3 \\
\hline $\mathrm{Ca}\left(\mathrm{mmol}_{\mathrm{c}} \mathrm{dm}^{-3}\right)$ & 60 & 32 & 31 \\
\hline $\operatorname{Mg}\left(\mathrm{mmol}_{\mathrm{c}} \mathrm{dm}^{-3}\right)$ & 19 & 11 & 9 \\
\hline Cation exchange capacity $\left(\mathrm{mmol}_{\mathrm{c}} \mathrm{dm}^{-3}\right)$ & 108 & 90 & 94 \\
\hline Base saturation (\%) & 75 & 49 & 46 \\
\hline $\mathrm{B}\left(\mathrm{mg} \mathrm{dm}^{-3}\right)$ & 0.33 & 0.64 & 0.77 \\
\hline $\mathrm{Cu}\left(\mathrm{mg} \mathrm{dm}^{-3}\right)$ & 8.3 & 1.2 & 6.2 \\
\hline $\mathrm{Fe}\left(\mathrm{mg} \mathrm{dm}^{-3}\right)$ & 60.7 & 44.0 & 32.7 \\
\hline $\operatorname{Mn}\left(\mathrm{mg} \mathrm{dm}^{-3}\right)$ & 24.6 & 8.2 & 9.3 \\
\hline $\mathrm{Zn}\left(\mathrm{mg} \mathrm{dm}^{-3}\right)$ & 1.04 & 1.55 & 2.88 \\
\hline Sand $\left(\mathrm{g} \mathrm{kg}^{-1}\right)$ & 311 & 292 & 153 \\
\hline Silt $\left(\mathrm{g} \mathrm{kg}^{-1}\right)$ & 289 & 184 & 245 \\
\hline Clay $\left(\mathrm{g} \mathrm{kg}^{-1}\right)$ & 400 & 524 & 602 \\
\hline
\end{tabular}

Soil tillage consisted of two heavy disk harrowing operations, chiseling, and light harrowing, which occurred on the day before planting. The potatoes were planted on 20 April 2011, 28 April 2011, and 20 May 2011 in the experiments with medium, low, and high soil $\mathrm{P}$ availability respectively. The furrows were mechanically opened with a furrower-planter, with $0.80-\mathrm{m}$ spacing between the furrows. Fertilizer was manually applied to the furrows. In the three experiments, the fertilization consisted of $62 \mathrm{~kg} \mathrm{~N}$ (ammonium sulfate, $20 \% \mathrm{~N}$ and $22 \% \mathrm{~S}$ ) per hectare and $124 \mathrm{~kg} \mathrm{~K}_{2} \mathrm{O}$ (potassium chloride, $60 \% \mathrm{~K}_{2} \mathrm{O}$ ) per hectare, applied to all plots. P fertilizer was also applied in the furrows according to the treatments. The fertilizers were manually incorporated into the soil with use of a hoe, and uncut seed tubers (35-g seed tubers with a diameter between 30 and $40 \mathrm{~mm}$ ) were spaced $0.30 \mathrm{~m}$ apart in the furrows. The pesticides thiamethoxam (155 $\mathrm{g}$ active ingredient per hectare), chlorpyrifos (557 $\mathrm{g}$ active ingredient per hectare), pencycuron (280 $\mathrm{g}$ active ingredient per hectare), metiram ( $77 \mathrm{~g}$ active ingredient per hectare), fluazinam (1.155 g active ingredient per hectare), and streptomycin (17 g active ingredient per hectare) were subsequently applied. Finally, the furrows were covered manually.

The plants emerged on 5 May 2011 (15 days after planting, DAP), 14 May 2011 (16 DAP), and 5 June 2011 (16 DAP) in the soil with medium, low, and high $\mathrm{P}$ availability respectively. Sidedressing fertilization was applied at 22 DAP in the experiment with low soil $\mathrm{P}$ availability, with use of $43 \mathrm{~kg} \mathrm{~N}$ (urea) per hectare, at 24 DAP in the experiment with medium soil P availability, with use of $64 \mathrm{~kg} \mathrm{~N}$ (urea) per hectare, and at 28 DAP in the experiment with high soil $\mathrm{P}$ availability, with use of $41 \mathrm{~kg} \mathrm{~N}$ (nitromag) per hectare. In all 


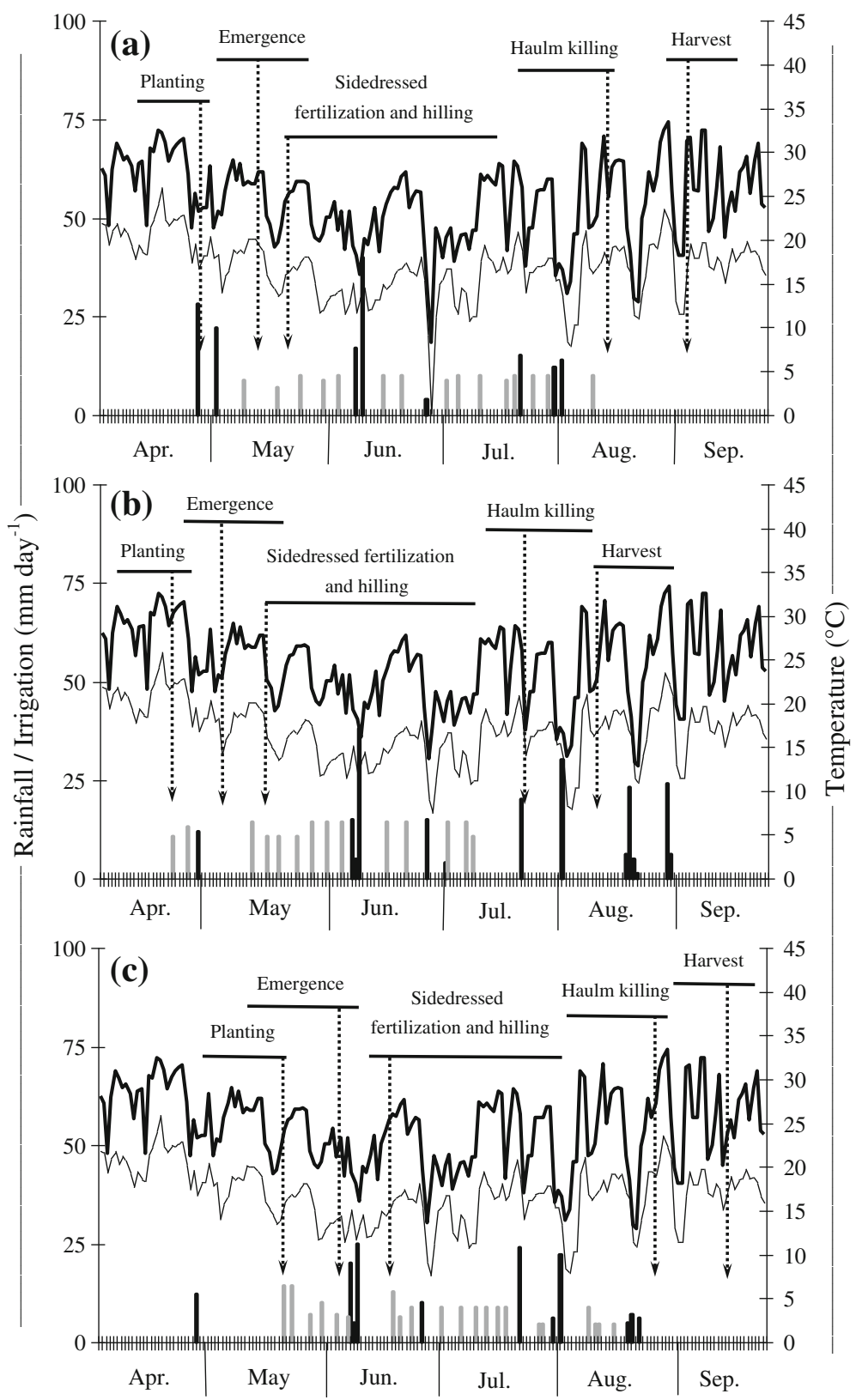

Fig. 1 Daily rainfall (vertical black bars), irrigation (vertical grey bars), and maximum (thick horizontal black lines) and minimum (thin horizontal black lines) temperatures at the experimental areas with low (a), medium (b), and high (c) soil P availability during the period from April to September 2011. The times of planting, emergence, sidedressed fertilization, hilling, haulm killing, and harvesting of the potato crops are indicated

experiments, thiamethoxam (150 g active ingredient per hectare), and fluazinam (1035 g active ingredient per hectare) were applied simultaneously with hilling immediately after sidedressing. 
Crop management was conducted in accordance with the regional cultural practices for potato crops, including sprinkler irrigation across all sites. The control of pests and diseases was accomplished with insecticides and fungicides recommended for potato crops.

Potato haulm killing was performed with the herbicide diquat (331 g active ingredient per hectare) on 23 July 2011 (94 DAP), 18 August 2011 (112 DAP), and 25 August 2011 (97 DAP) in the experiments with medium, low and high soil P availability respectively.

\section{Plant Assessment and Sampling}

The third-expanded leaf from the apex was collected from 15 randomly selected plants per plot at 29 days after emergence (45 DAP) in the experiments with low and high $\mathrm{P}$ availability, whereas in the experiment with medium $P$ availability, the leaf sampling was conducted at 32 days after emergence (47 DAP). The leaves were washed with deionized water and dried in an oven with forced-air circulation at $65^{\circ} \mathrm{C}$.

In all experiments, four plants at the tuber maturation stage were collected from the analysis area of each plot 1 day before haulm killing. These plants were divided into tubers, roots, and shoots (leaves, stems, and stolons). All plant parts were washed with deionized water. Each fresh tuber sample was weighed, and a subsample was collected, which was weighed (fresh weight), sliced, and dried in an oven with forced-air circulation at $65^{\circ} \mathrm{C}$ for $96 \mathrm{~h}$, separate from the other plant parts. The plant shoots of each sample were divided into three or four subsamples, placed separately into paper bags with 15-kg capacity, and dried in an oven with forced-air circulation at $65{ }^{\circ} \mathrm{C}$ for $96 \mathrm{~h}$. The root samples were dried in the same way as the plant shoots but were not divided into subsamples. The dry plant parts were weighed, and the dry matter (DM) accumulation in the tubers and the rest of the plant (shoots and roots) was calculated.

The potatoes were harvested on 12 August 2011 (114 DAP), 4 September 2011 (129 DAP), and 15 September 2011 (118 DAP) in the experiments with medium, low, and high soil $\mathrm{P}$ availability respectively. Tubers from two $1.5-\mathrm{m}$-long rows (ten plants) in the useful area of each plot were excavated with a spade and collected manually. The tubers were graded to determine the total yield and the yield of tubers with a transverse diameter larger than $45 \mathrm{~mm}$. After they had been sorted, the tubers were counted and weighed to determine the number of tubers per plant, tuber mean weight, and total tuber yield and yield of tubers with a diameter larger than $45 \mathrm{~mm}$. The tuber samples were sliced and dried in an oven with forced-air circulation at $65{ }^{\circ} \mathrm{C}$ for $96 \mathrm{~h}$.

All dry plant tissues were separately ground to pass through a 40-mesh stainless steel sieve for subsequent chemical analysis.

\section{Phosphorus Determinations in Plant Tissues}

All of the dry plant tissues (third expanded leaves, tubers, and the rest of the plants collected before shoot desiccation, and tubers at harvest) were chemically analysed to determine the $\mathrm{P}$ concentrations. The $\mathrm{P}$ concentrations were determined by atomic absorption spectrophotometry after $\mathrm{HNO}_{3}$ (nitric acid) and $\mathrm{HClO}_{4}$ (perchloric acid) digestion (Malavolta et al. 1997). 
$\mathrm{P}$ uptake by whole plants was calculated as the sum of the amounts of $\mathrm{P}$ that accumulated in the tubers and the rest of the plant before haulm killing. The amount of $\mathrm{P}$ that accumulated in the tubers and the rest of the plant was calculated by multiplication of the $\mathrm{P}$ concentration of each plant organ (tubers, shoots, and roots) by the amount of accumulated DM.

$\mathrm{P}$ removal by tubers at harvest was calculated by multiplication of the $\mathrm{P}$ concentration and the DM of the tubers at harvest.

\section{Fertilizer Phosphorus Recovery, Relative Tuber Yield, and Applied Phosphorus Use Efficiency}

The percent FPR was calculated by the traditional method, with the following equation presented by Chien et al. (2012): FPR $(\%)=[(\mathrm{P}$ uptake from soil treated with $\mathrm{P}$ fertilizer $-\mathrm{P}$ uptake from the control)/amount of $\mathrm{P}$ fertilizer applied] $\times 100$.

Relative tuber yield was calculated for each $\mathrm{P}$ fertilization rate as the ratio between the tuber yield for each $\mathrm{P}$ fertilization rate and the maximum tuber yield measured in the experiment. The APUE for tuber yield in a treatment was determined by division of the difference between the tuber yield of the respective $\mathrm{P}$ fertilization rate and the tuber yield without $\mathrm{P}$ application (control) by the $\mathrm{P}_{2} \mathrm{O}_{5}$ fertilization rate.

\section{Statistical Analysis}

The data were analysed with the SISVAR statistical software package (Ferreira 2011). The blocks and all of the block interactions were considered as random effects. The soil $\mathrm{P}$ availability (experiment), cultivar, and $\mathrm{P}$ fertilization rate were considered as fixed effects. For soil $\mathrm{P}$ availability and cultivar, the means were compared by Tukey's test at the 0.05 probability level. Regression analysis was performed to determine the $\mathrm{P}$ fertilization rate response curves for several measured potato traits (dependent variables), for which significant regression equations with the highest coefficients of determination and those that best explained the relationship between the $\mathrm{P}$ fertilization rates and dependent variables were selected and plotted with SigmaPlot 10.0 (Systat Software, San Jose, CA, USA). In addition to the soil $\mathrm{P}$ availability, the experiments also differed with respect to the date of planting and the climate conditions (Fig. 1), which may have influenced the performance of each cultivar even more than the soil $\mathrm{P}$ availability. However, the primary objective was to study the response of the potato cultivars to the rates of $\mathrm{P}$ applied to soil with different levels of $\mathrm{P}$ availability, and we did not consider significant soil $\mathrm{P}$ availability (experiment) $\times$ cultivar interactions. To analyse the other significant interactions, the soil $\mathrm{P}$ availability and cultivar means were separated by Tukey's test at the 0.05 probability level, and the regression equations were adjusted to the values of each soil $\mathrm{P}$ availability and cultivar separately. The $\mathrm{P}_{2} \mathrm{O}_{5}$ fertilization rates that resulted in the maximum values of each variable were obtained from the inflection or stabilization point of the plotted curves for each condition of $P$ availability in the soil (experiment) and/or cultivar. 


\section{Results}

The leaf $\mathrm{P}$ concentrations were affected by the soil $\mathrm{P}$ availability, cultivar, $\mathrm{P}$ fertilization rate, and soil $\mathrm{P}$ availability $\times \mathrm{P}$ fertilization rate interaction (Table 2). The highest leaf $\mathrm{P}$ concentration was measured in the cultivar Agata, and the lowest concentrations were measured in the cultivars Asterix and Atlantic. In the absence of phosphate fertilizer applied in the planting furrow, the potato plants grown in soil with low $\mathrm{P}$ availability had leaf $\mathrm{P}$ concentrations lower than those grown in the other soils, but with increasing $P$ fertilization rates, the leaf $P$ concentrations were similar for all soils (Fig. 2a). In the soil with low $\mathrm{P}$ availability, the leaf $\mathrm{P}$ concentrations increased up to the highest rate of $\mathrm{P}$ applied, but in soils with medium and high $\mathrm{P}$ availability, an increase in leaf $\mathrm{P}$ concentration occurred until approximately $850 \mathrm{~kg} \mathrm{P}_{2} \mathrm{O}_{5}$ per hectare.

The DM accumulation in the tubers, the rest of the plant, and the whole plant was affected by the soil $\mathrm{P}$ availability, cultivar, $\mathrm{P}$ application rate, and soil $\mathrm{P}$ availability $\times \mathrm{P}$ application rate interaction (Table 2). The highest DM accumulation in the tubers and

Table 2 Leaf $\mathrm{P}$ concentration, dry matter accumulation, $\mathrm{P}$ concentration in different plant parts, total $\mathrm{P}$ uptake, and fertilizer $\mathrm{P}$ recovery $(F P R)$ of the potato crop as affected by soil $\mathrm{P}$ availability, cultivar, and $\mathrm{P}$ application rate. The ANOVA significance levels are presented

\begin{tabular}{|c|c|c|c|c|c|c|c|c|}
\hline \multirow[t]{2}{*}{ Treatment } & \multirow{2}{*}{$\begin{array}{l}\text { Leaf } P \\
\text { concentration } \\
\left(\mathrm{g} \mathrm{kg}^{-1}\right)\end{array}$} & \multicolumn{3}{|c|}{$\begin{array}{l}\text { Dry matter accumulation } \\
\left(\mathrm{kg} \mathrm{ha}^{-1}\right)\end{array}$} & \multicolumn{2}{|c|}{$\begin{array}{l}\text { P concentration } \\
\left(\mathrm{g} \mathrm{kg}^{-1}\right)\end{array}$} & \multirow[t]{2}{*}{$\begin{array}{l}\text { Total P uptake } \\
\left(\mathrm{kg} \mathrm{ha}^{-1}\right)\end{array}$} & \multirow[t]{2}{*}{$\begin{array}{l}\text { FPR } \\
(\%)\end{array}$} \\
\hline & & Tubers & $\begin{array}{l}\text { Rest of the } \\
\text { plant }\end{array}$ & $\begin{array}{l}\text { Whole } \\
\text { plant }\end{array}$ & Tubers & $\begin{array}{l}\text { Rest of the } \\
\text { plant }\end{array}$ & & \\
\hline \multicolumn{9}{|c|}{ Soil $\mathrm{P}$ availability } \\
\hline Low & $3.6 \mathrm{c}$ & $2986 \mathrm{c}$ & $449 \mathrm{c}$ & $3435 \mathrm{c}$ & $2.4 \mathrm{a}$ & $2.0 \mathrm{~b}$ & $8 \mathrm{c}$ & $5.4 \mathrm{a}$ \\
\hline Medium & $4.0 \mathrm{~b}$ & $5158 \mathrm{~b}$ & $911 \mathrm{~b}$ & $6069 \mathrm{~b}$ & $2.2 \mathrm{~b}$ & $2.0 \mathrm{~b}$ & $13 \mathrm{~b}$ & $4.0 \mathrm{~b}$ \\
\hline High & $4.4 \mathrm{a}$ & $5461 \mathrm{a}$ & $994 \mathrm{a}$ & $6455 \mathrm{a}$ & $2.1 \mathrm{~b}$ & $2.2 \mathrm{a}$ & $14 \mathrm{a}$ & $3.8 \mathrm{~b}$ \\
\hline \multicolumn{9}{|l|}{ Cultivar } \\
\hline Agata & $4.6 \mathrm{a}$ & $3773 \mathrm{~d}$ & $752 \mathrm{~b}$ & $4526 \mathrm{~d}$ & $2.4 \mathrm{a}$ & $2.1 \mathrm{a}$ & $11 \mathrm{~cd}$ & $3.6 \mathrm{c}$ \\
\hline Asterix & $3.7 \mathrm{c}$ & $4819 \mathrm{~b}$ & $789 \mathrm{~b}$ & $5608 \mathrm{~b}$ & $2.2 \mathrm{~b}$ & $2.1 \mathrm{a}$ & $12 \mathrm{~b}$ & $4.5 \mathrm{~b}$ \\
\hline Atlantic & $3.6 \mathrm{c}$ & $4000 \mathrm{~d}$ & $765 \mathrm{~b}$ & $4764 \mathrm{~cd}$ & $2.1 \mathrm{~b}$ & $2.3 \mathrm{a}$ & $10 \mathrm{~d}$ & $3.7 \mathrm{c}$ \\
\hline Markies & $4.0 \mathrm{~b}$ & $4381 \mathrm{c}$ & $727 \mathrm{~b}$ & $5109 \mathrm{c}$ & $2.4 \mathrm{a}$ & $2.1 \mathrm{a}$ & $12 \mathrm{~b}$ & $4.5 \mathrm{~b}$ \\
\hline Mondial & $4.1 \mathrm{~b}$ & $5702 \mathrm{a}$ & $891 \mathrm{a}$ & $6592 \mathrm{a}$ & $2.0 \mathrm{~b}$ & $1.8 \mathrm{~b}$ & $13 \mathrm{a}$ & $5.6 \mathrm{a}$ \\
\hline ANOVA & $P>F$ & & & & & & & \\
\hline SP & $<0.001$ & $<0.001$ & $<0.001$ & $<0.001$ & $<0.001$ & $<0.001$ & $<0.001$ & $<0.001$ \\
\hline $\mathrm{C}$ & $<0.001$ & $<0.001$ & $<0.001$ & $<0.001$ & $<0.001$ & $<0.001$ & $<0.001$ & $<0.001$ \\
\hline $\mathrm{SP} \times \mathrm{C}$ & 0.019 & $<0.001$ & 0.001 & $<0.001$ & 0.005 & 0.003 & $<0.001$ & $<0.001$ \\
\hline PR & $<0.001$ & $<0.001$ & $<0.001$ & $<0.001$ & $<0.001$ & $<0.001$ & $<0.001$ & $<0.001$ \\
\hline $\mathrm{SP} \times \mathrm{PR}$ & $<0.001$ & $<0.001$ & 0.014 & $<0.001$ & 0.050 & 0.007 & $<0.001$ & $<0.001$ \\
\hline $\mathrm{C} \times \mathrm{PR}$ & NS & NS & NS & NS & NS & NS & NS & $<0.001$ \\
\hline $\begin{array}{l}\mathrm{SP} \times \\
\mathrm{C} \times \mathrm{PR}\end{array}$ & NS & NS & NS & NS & NS & NS & NS & NS \\
\hline
\end{tabular}

Values within a column for a particular factor (soil P availability or cultivar) followed by the same letter are not significantly different at $P \leq 0.05$ according to Tukey's test

$C$ cultivar, $N S$ not significant at $P \leq 0.05, P R \mathrm{P}$ application rate, $S P$ soil $\mathrm{P}$ availability 

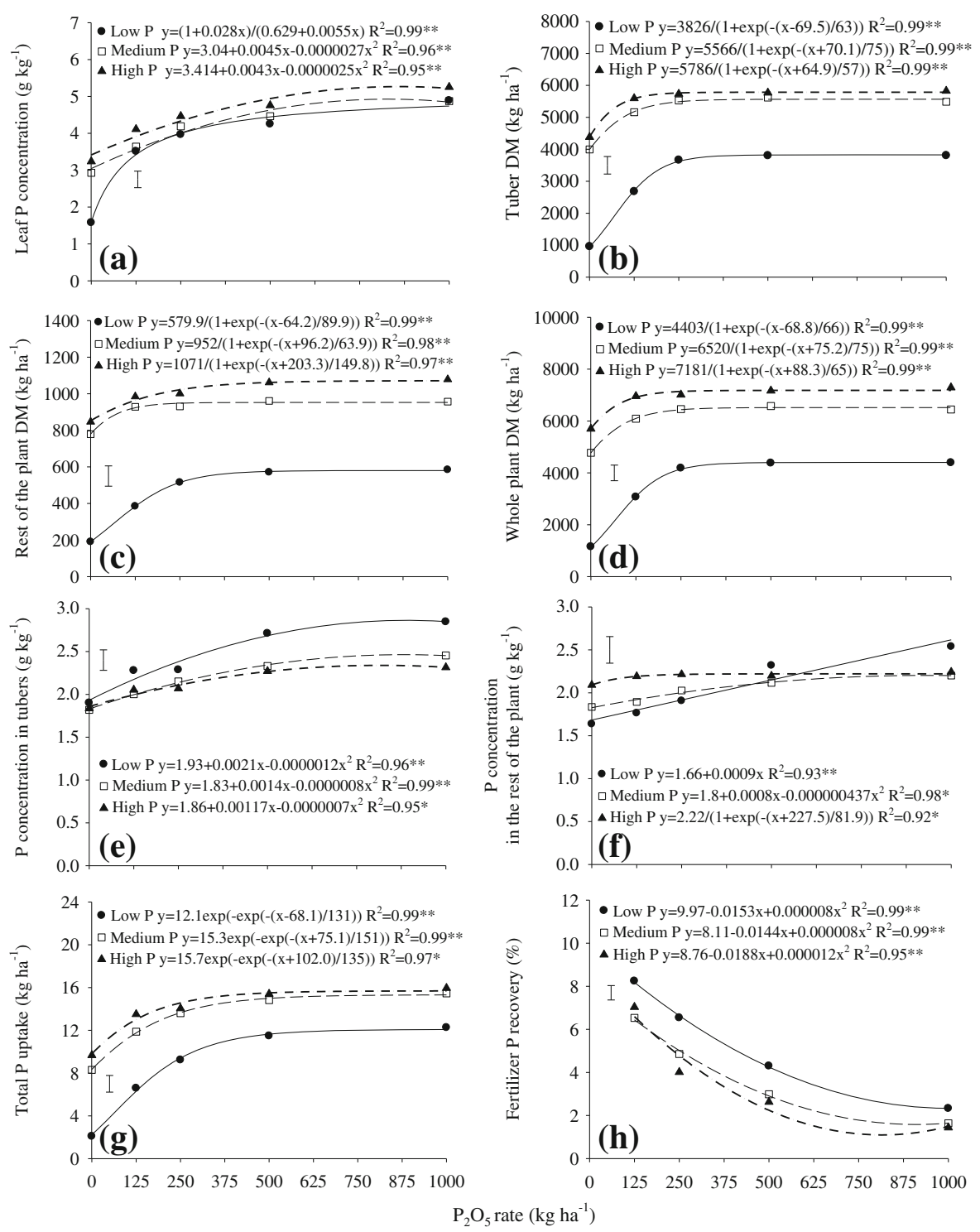

Fig. 2 Leaf $\mathrm{P}$ concentration (a), dry mater $(D M)$ accumulation in the tubers (b), DM accumulation in the rest of the plant (c), DM accumulation in the whole plant $(\mathbf{d}), \mathrm{P}$ concentration in the tubers $(\mathbf{e})$, $\mathrm{P}$ concentration in the rest of the plant (f), total P uptake $(\mathbf{g})$, and fertilizer P recovery $(\mathbf{h})$ of the potato crop as affected by soil $\mathrm{P}$ availability and $\mathrm{P}$ application rate. The data presented are the average values of the five cultivars. Vertical bars represent the least significant difference at $P \leq 0.05$ according to Tukey's test for the soil $\mathrm{P}$ availabilities at the same $\mathrm{P}$ application rate. One asterisk $P<0.05$, two asterisks $P<0.01$

the whole plant was observed in the cultivar Mondial, and the lowest was observed in the cultivars Agata and Atlantic. The cultivar Mondial had the highest DM accumulation in the rest of the plant compared with the other cultivars. The application of phosphate fertilizer increased the DM accumulation in the tubers, the rest of the plant and the whole plant up to $500 \mathrm{~kg} \mathrm{P}_{2} \mathrm{O}_{5}$ per hectare in the soil with low $\mathrm{P}$ availability, 
and up to $250 \mathrm{~kg} \mathrm{P}_{2} \mathrm{O}_{5}$ per hectare in the soils with medium and high initial $\mathrm{P}$ availability (Fig. 2b-d). In the soil with low P availability, less DM accumulated, regardless of the $\mathrm{P}$ application rate, but the response to phosphate fertilization was, on average, between 1.8- and 2.6-fold higher than in the other soils/experiments.

There were soil $\mathrm{P}$ availability, cultivar, $\mathrm{P}$ application rate, and soil $\mathrm{P}$ availability $\times \mathrm{P}$ application rate interaction effects on the total $\mathrm{P}$ uptake and the $\mathrm{P}$ concentrations in the tubers and the rest of the plant (Table 2). In the tubers, the lowest $\mathrm{P}$ concentrations were measured in the cultivars Mondial, Asterix, and Atlantic, whereas the cultivar Mondial had the lowest $\mathrm{P}$ concentration in the rest of the plant. The cultivar Mondial took up the highest amounts of $\mathrm{P}$, whereas the cultivars Agata and Atlantic accumulated the lowest amounts. The $\mathrm{P}$ concentrations in the tubers increased up to estimated fertilization rates of between 830 and $875 \mathrm{~kg} \mathrm{P}_{2} \mathrm{O}_{5}$ per hectare, regardless of the initial soil $\mathrm{P}$ availability (Fig. 2e). In the soil with high $\mathrm{P}$ availability, application of phosphate fertilizer resulted in only a slight increase in the $\mathrm{P}$ concentration in the rest of the plant, but in the soils with lower $\mathrm{P}$ availability, the $\mathrm{P}$ concentrations increased up to the highest rate of $\mathrm{P}$ application studied (Fig. 2f). In the soil with low available $P$, the $P$ concentration in the rest of the plant was lower than that in the soil with the high available $\mathrm{P}$, but only at fertilizer application rates below $250 \mathrm{~kg} \mathrm{P}_{2} \mathrm{O}_{5}$ per hectare. On the other hand, at the highest rates of $\mathrm{P}$ applied, the highest concentrations of $\mathrm{P}$ in the tubers were observed for the soil with th low initial $\mathrm{P}$ availability (Fig. 2e). Under all three conditions of soil $\mathrm{P}$ availability, $\mathrm{P}$ uptake increased up to an application rate of $500 \mathrm{~kg} \mathrm{P}_{2} \mathrm{O}_{5}$ per hectare, but in the soil with low $\mathrm{P}$ availability, the increase in $\mathrm{P}$ uptake was approximately twice that measured in the soils that were the most fertile with respect to P (Fig. $2 \mathrm{~g}$ ). At all application rates of $\mathrm{P}$ studied, the amounts of $\mathrm{P}$ taken up by the potato plants were lower in the soil with low P availability than in the other two soils.

The FPR was affected by the soil $\mathrm{P}$ availability, cultivar, $\mathrm{P}$ application rate, and soil $\mathrm{P}$ availability $\times \mathrm{P}$ application rate and cultivar $\times \mathrm{P}$ application rate interactions (Table 2). The FPR decreased with increasing rates of $\mathrm{P}$ fertilizer application, regardless of the cultivar and initial P availability of the soil (Fig. 2h, Table 3). However, in the soil with low P availability, the FPR was higher than in the others soils, especially at low $\mathrm{P}$ application rates (Fig. 2h). At low $\mathrm{P}$ application rates (125, 250, and $500 \mathrm{~kg} \mathrm{P}_{2} \mathrm{O}_{5}$ per hectare), the cultivar Mondial had the highest FPR; at higher P application rates, however, there were no differences among the cultivars (Table 3).

The number of tubers (total and number with a diameter larger than $45 \mathrm{~mm}$ ) per plant, the mean weight per tuber, and the tuber yield (total and yield of tubers with a diameter larger than $45 \mathrm{~mm}$ ) of the potato crop were affected by the soil $\mathrm{P}$ availability, cultivar, $\mathrm{P}$ application rate, and soil $\mathrm{P}$ availability $\times \mathrm{P}$ application rate interaction (Table 4). The cultivars Agata, Asterix, and Mondial produced high total numbers of tubers per plant, but only the cultivars Agata and Mondial produced a large number of tubers with a diameter larger than $45 \mathrm{~mm}$. The cultivar Mondial also produced tubers with a higher mean weight and yield (total and yield of tubers with a diameter larger than $45 \mathrm{~mm}$ ) compared with the other cultivars. Regardless of the initial P availability in the soil, the total number of tubers per plant increased significantly up to a rate of $125 \mathrm{~kg} \mathrm{P} \mathrm{O}_{5}$ per hectare, whereas the number of tubers larger than $45 \mathrm{~mm}$ increased up to a rate of $250 \mathrm{~kg} \mathrm{P}_{2} \mathrm{O}_{5}$ per hectare in the soils with low and medium $\mathrm{P}$ availability, and only up to $125 \mathrm{~kg} \mathrm{P}_{2} \mathrm{O}_{5}$ per hectare in the soil with high availability of this nutrient (Fig. 3a, b). In the absence of phosphate fertilization, the number of tubers per plant 
Table 3 Fertilizer P recovery (FPR) and applied P use efficiency (APUE) of the potato crop as affected by the cultivar and $\mathrm{P}$ application rate. The average values of the three soil $\mathrm{P}$ availabilities are presented

\begin{tabular}{|c|c|c|c|c|c|c|}
\hline \multirow[t]{2}{*}{ Cultivar } & \multicolumn{4}{|c|}{$\mathrm{P}_{2} \mathrm{O}_{5}$ application rate $\left(\mathrm{kg} \mathrm{ha}^{-1}\right)$} & \multirow[t]{2}{*}{ Regression } & \multirow[t]{2}{*}{$R^{2}$} \\
\hline & 125 & 250 & 500 & 1000 & & \\
\hline & \multicolumn{6}{|c|}{$\operatorname{FPR}(\%)$} \\
\hline Agata & $6.0 \mathrm{c}$ & $4.1 \mathrm{c}$ & $2.6 \mathrm{~b}$ & $1.5 \mathrm{a}$ & $y=7.40-0.0138 x+0.000008 x^{2}$ & $0.99 * *$ \\
\hline Asterix & $7.6 \mathrm{~b}$ & $5.4 \mathrm{~b}$ & $3.2 \mathrm{~b}$ & $1.8 \mathrm{a}$ & $y=9.54-0.0183 x+0.000011 x^{2}$ & $0.99 * *$ \\
\hline Atlantic & $5.9 \mathrm{c}$ & $4.5 \mathrm{bc}$ & $2.9 \mathrm{~b}$ & $1.6 \mathrm{a}$ & $y=7.22-0.0118 x+0.000006 x^{2}$ & $0.99 * *$ \\
\hline Markies & $7.6 \mathrm{~b}$ & $5.1 \mathrm{bc}$ & $3.6 \mathrm{ab}$ & $1.9 \mathrm{a}$ & $y=9.21-0.0164 x+0.000009 x^{2}$ & $0.97 * *$ \\
\hline \multirow[t]{2}{*}{ Mondial } & $9.3 \mathrm{a}$ & $6.5 \mathrm{a}$ & $4.2 \mathrm{a}$ & $2.3 \mathrm{a}$ & $y=11.38-0.0205 x+0.000011 x^{2}$ & $0.99 * *$ \\
\hline & \multicolumn{6}{|c|}{$\operatorname{APUE}\left(\mathrm{kg} \mathrm{kg}^{-1}\right)^{\mathrm{a}}$} \\
\hline Agata & $62 \mathrm{~b}$ & $41 \mathrm{bc}$ & $21 \mathrm{~b}$ & $12 \mathrm{a}$ & $y=80.5-0.175649 x+0.000107 x^{2}$ & $0.99^{* * *}$ \\
\hline Asterix & $61 \mathrm{~b}$ & $46 \mathrm{~b}$ & $23 \mathrm{ab}$ & $12 \mathrm{a}$ & $y=78.5-0.153322 x+0.000087 x^{2}$ & $0.99 * *$ \\
\hline Atlantic & $54 \mathrm{c}$ & $35 \mathrm{c}$ & $20 \mathrm{~b}$ & $10 \mathrm{a}$ & $y=69.2-0.145066 x+0.000086 x^{2}$ & $0.98 * *$ \\
\hline Markies & $54 \mathrm{c}$ & $37 \mathrm{c}$ & $21 \mathrm{~b}$ & $10 \mathrm{a}$ & $y=68.7-0.137897 x+0.00008 x^{2}$ & $0.99 * *$ \\
\hline Mondial & $100 \mathrm{a}$ & $58 \mathrm{a}$ & $29 \mathrm{a}$ & $15 \mathrm{a}$ & $y=130.8-0.308669 x+0.000194 x^{2}$ & $0.98 * *$ \\
\hline
\end{tabular}

Values within a column followed by the same letter are not significantly different at $P \leq 0.05$ according to Tukey's test for the cultivars at the same $\mathrm{P}$ application rate. Two asterisks: $P<0.01$

${ }^{\text {a }}$ Kilograms of tubers per kilogram of $\mathrm{P}_{2} \mathrm{O}_{5}$

was higher in the soils with greater $\mathrm{P}$ availability, but at a rate from $250 \mathrm{~kg} \mathrm{P}_{2} \mathrm{O}_{5}$ per hectare upwards, the total number of tubers per plant was similar in all soils, whereas the number of tubers with a diameter larger than $45 \mathrm{~mm}$ was higher in the soils with medium and high initial $\mathrm{P}$ availability. The phosphate fertilization increased the mean weight per tuber in all soils up to a rate of $500 \mathrm{~kg} \mathrm{P}_{2} \mathrm{O}_{5}$ per hectare, but in the soil with low $\mathrm{P}$ availability, the relative increase in the size of the tubers was 6.5-fold higher (Fig. 3c). At all P application rates, the tuber mean weight was lower in the soil with a low concentration of available $P$.

Application of phosphate fertilizer increased the total tuber yield, relative tuber yield, and yield of tubers with a diameter larger than $45 \mathrm{~mm}$ up to application rates of 500, 250, and $125 \mathrm{~kg} \mathrm{P}_{2} \mathrm{O}_{5}$ per hectare in the soils with low, medium, and high $\mathrm{P}$ availability respectively (Fig. $4 \mathrm{a}-\mathrm{c}$ ). In the soils with medium and high $\mathrm{P}$ availability, the tuber yield did not differ and was higher than in the soil with low P availability. In comparison with the maximum total yields reached, the absence of $\mathrm{P}$ application reduced the tuber yield of the potato crop by $76 \%, 30 \%$, and $18 \%$ respectively in the soils with low, medium, and high $\mathrm{P}$ availability (Fig. 4b).

There were soil $\mathrm{P}$ availability, cultivar, $\mathrm{P}$ application rate, and soil $\mathrm{P}$ availability $\times \mathrm{P}$ application rate and cultivar $\times \mathrm{P}$ application rate interaction effects on the APUE (Table 4). Regardless of the cultivar and soil P availability, the APUE decreased in response to increasing rates of $\mathrm{P}$ application, up to essentially the same rates of $\mathrm{P}_{2} \mathrm{O}_{5}$ applied, i.e. the highest rate (Fig. 4d, Table 3). At lower P application rates, higher APUEs were observed in the soil with low initial P availability compared with the other soils, and the cultivar Mondial had a $36 \%$ higher APUE compared with the average 


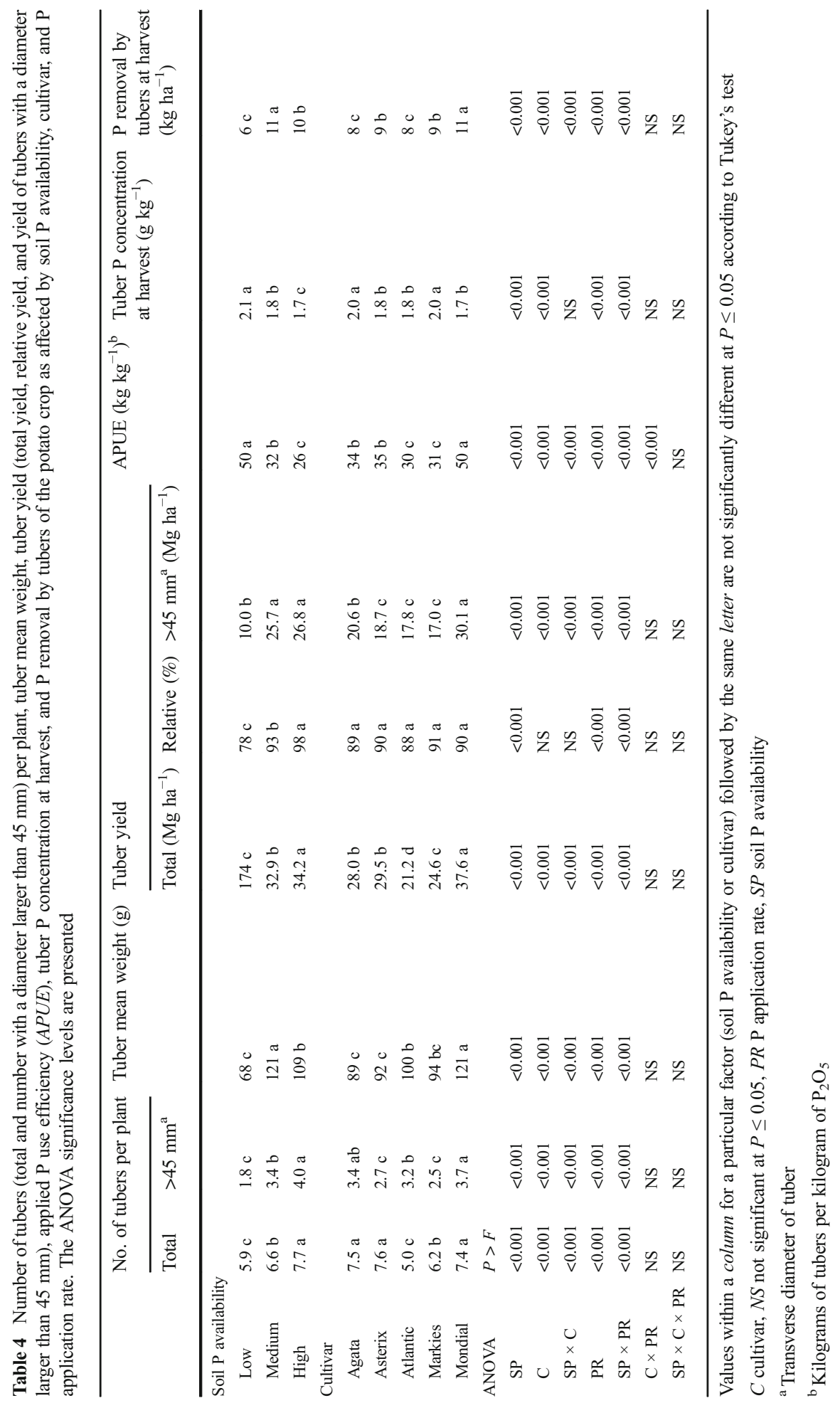




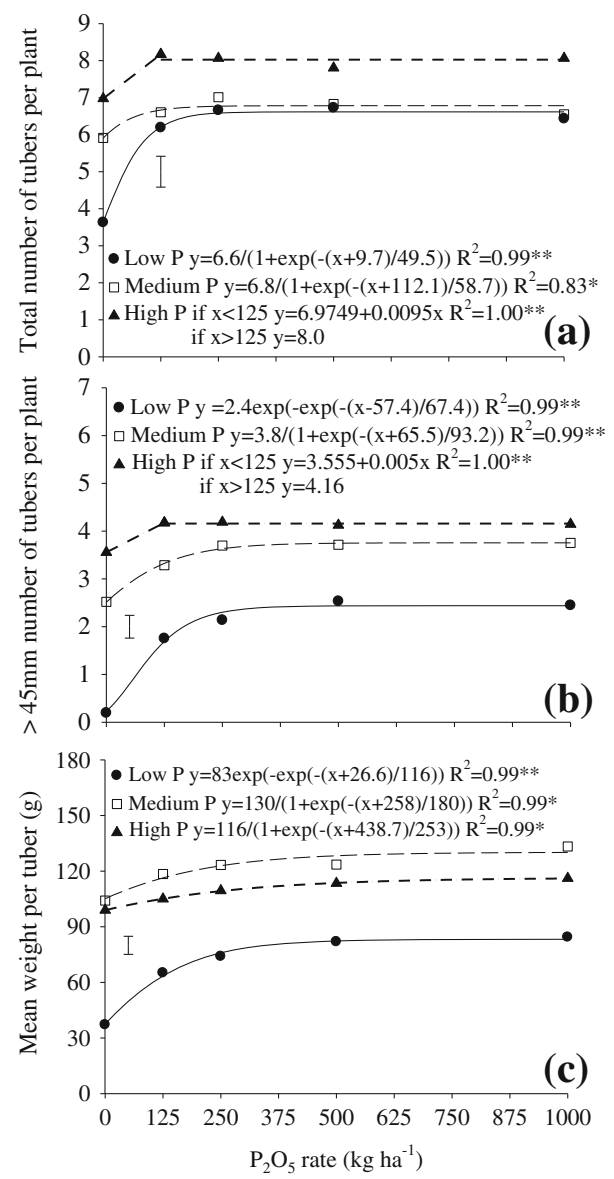

Fig. 3 Total number of tubers per plant (a), number of tubers with a diameter larger than $45 \mathrm{~mm}$ per plant (b) and mean weight per tuber (c) of the potato crop as affected by soil $\mathrm{P}$ availability and $\mathrm{P}$ application rate. The data presented are the average values of the five cultivars. Vertical bars represent the least significant difference at $P \leq 0.05$ according to Tukey's test for the soil $\mathrm{P}$ availabilities at the same $\mathrm{P}$ application rate. One asterisk $P<0.05$, two asterisks $P<0.01$

value of the other cultivars. However, all cultivars had the same APUE at $1000 \mathrm{~kg} \mathrm{P}_{2} \mathrm{O}_{5}$ per hectare (Table 3).

The $\mathrm{P}$ concentration and $\mathrm{P}$ removal by the tubers at harvest were affected by the soil $\mathrm{P}$ availability, cultivar, $\mathrm{P}$ application rate, and soil $\mathrm{P}$ availability $\times \mathrm{P}$ application rate interaction (Table 4). The cultivars Agata and Markies had the highest $\mathrm{P}$ concentrations in the tubers, but greater P removal was observed in the cultivar Mondial, due to higher tuber yield. In the soil with medium $P$ availability, the increase in the rate of phosphate fertilizer application linearly increased the $\mathrm{P}$ concentration in the tubers, but in the soils with low and high $\mathrm{P}$ availability, increases in $\mathrm{P}$ concentration occurred up to estimated application rates of 875 and $820 \mathrm{~kg} \mathrm{P}_{2} \mathrm{O}_{5}$ per hectare respectively (Fig. 4e). At lower $\mathrm{P}$ application rates, the $\mathrm{P}$ concentrations in the tubers did not differ between the soils/ experiments, but at rates from $250 \mathrm{~kg} \mathrm{P}_{2} \mathrm{O}_{5}$ per hectare, the $\mathrm{P}$ concentrations in the tubers were higher in the soil with low $\mathrm{P}$ availability and were at intermediate levels in 

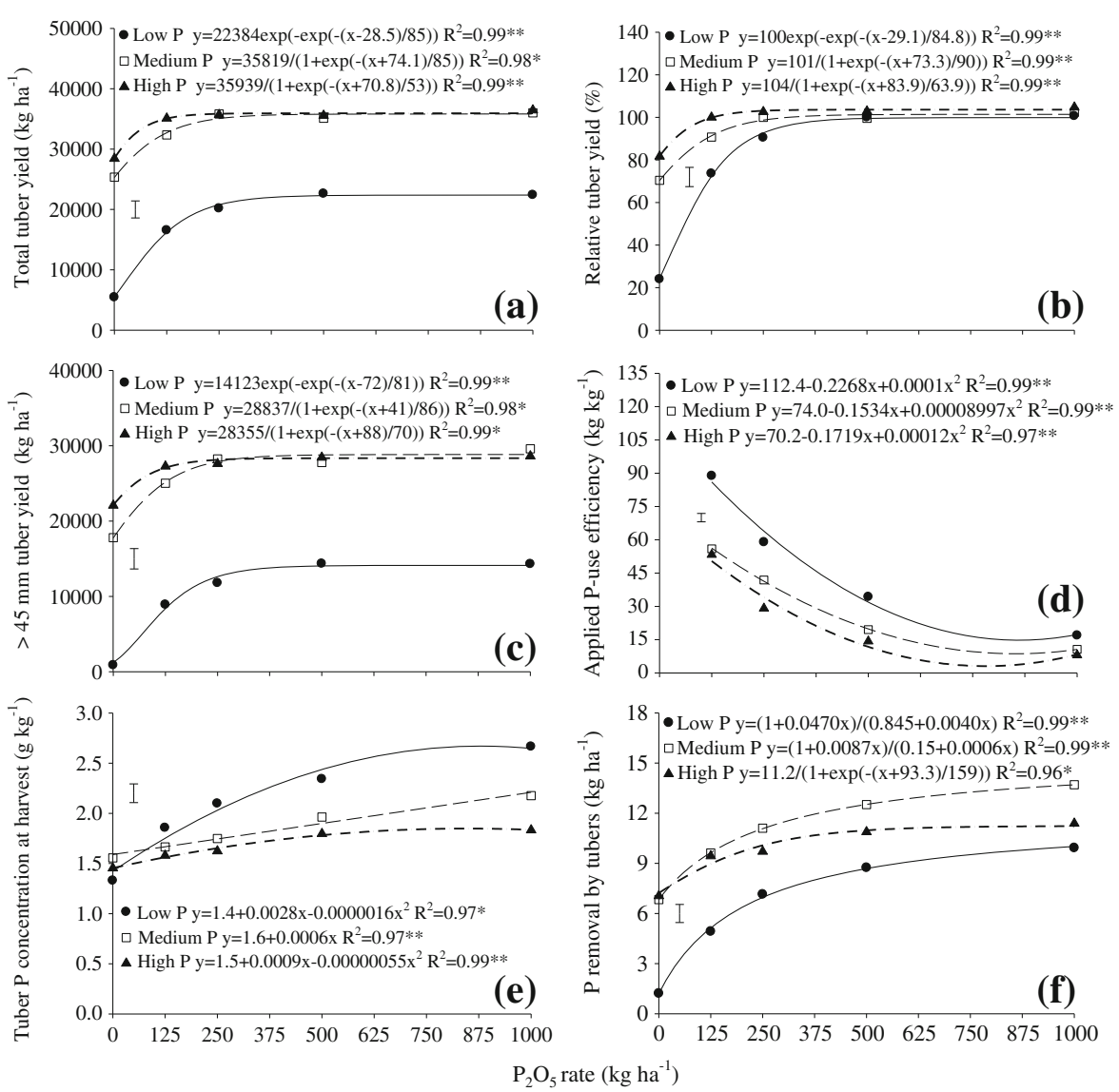

Fig. 4 Total tuber yield (a), relative tuber yield (b), yield of tubers with a diameter larger than $45 \mathrm{~mm}(\mathbf{c})$, applied P use efficiency (d), tuber P concentration at harvest (e), and P removal by tubers (f) for the potato crop affected by soil $\mathrm{P}$ availability and $\mathrm{P}$ application rate. The data presented are the average values of the five cultivars. Vertical bars represent the least significant difference at $P \leq 0.05$ according to Tukey's test for the soil $\mathrm{P}$ availabilities at the same $\mathrm{P}$ application rate. One asterisk $P<0.05$, two asterisks $P<0.01$

the soil with medium nutrient availability. The removal of $\mathrm{P}$ increased up to the highest rate of $\mathrm{P}$ application studied in the soils with low and medium $\mathrm{P}$ availability, but only up to a rate of $500 \mathrm{~kg} \mathrm{P}_{2} \mathrm{O}_{5}$ per hectare in the soil with high $\mathrm{P}$ availability (Fig. $4 \mathrm{f}$ ). At lower $\mathrm{P}$ application rates, the removal of this nutrient by the tubers was similar in the soils with medium and high $\mathrm{P}$ availability, and higher than in the soil with low $\mathrm{P}$ availability. At the highest $\mathrm{P}$ application rate, the greatest removal of $\mathrm{P}$ was observed in the soil with medium $P$ availability.

\section{Discussion}

The cultivar Agata had the highest leaf P concentrations and the cultivars Asterix and Atlantic had the lowest, but because the cultivar $\times \mathrm{P}$ application rate interaction was not significant (Table 2), there was no reason to evaluate the P-nutritional status separately 
by cultivar, even though small differences occurred between the leaf $\mathrm{P}$ concentrations of some cultivars, as was also observed by Fernandes et al. (2011b). The P concentrations in the leaves increased with phosphate fertilization under all conditions of initial soil $\mathrm{P}$ availability; only in the soil with low $\mathrm{P}$ availability were the leaf $\mathrm{P}$ concentrations in the control treatment lower than the deficiency limit of $2.5 \mathrm{~g} \mathrm{~kg}^{-1}$ proposed by Lorenzi et al. (1997) (Fig. 2a).

The cultivar Mondial accumulated more DM in all plant parts compared with the other cultivars, and the cultivars Agata and Atlantic accumulated the lowest amounts of DM in the tubers and the whole plant (Table 2). According to Fernandes et al. (2010), the cultivars Agata and Atlantic had lower DM production because of their lower DM accumulation rates in the whole plant, which were 25-32\% lower than the rate measured for the cultivar Mondial. The absence of a significant cultivar $\times \mathrm{P}$ application rate interaction shows that, despite the differences in the growth (Table 2), the DM accumulation of these cultivars in response to $\mathrm{P}$ supply was similar (Fig. 2). The increase in the DM production in response to phosphate fertilization was greater and occurred until higher $\mathrm{P}$ application rates in the soil with low $\mathrm{P}$ availability compared with the other soils (Fig. 2b-d). This is consistent with the finding that in soils with higher $\mathrm{P}$ availability, the application of phosphate fertilizer at high rates does not increase the DM of plants because the residual concentration of soil available $\mathrm{P}$ is sufficient to generate satisfactory DM yields (Ali and Anjum 2004). Also, Liu et al. (2015) found that under the condition of higher $P$ availability in the soil, the application of phosphate fertilizer increased potato growth to a smaller extent than in soil with lower $\mathrm{P}$ availability.

Our results showed that the differences among cultivars with respect to the $\mathrm{P}$ concentrations in the plant were clearly related to their DM production (Table 2). The lower P concentrations in the tubers of the cultivars Mondial, Asterix, and Atlantic and in the rest of the plant of the cultivar Mondial occurred because of a dilution effect caused by the greater DM accumulation in these plant parts. The initial P availability in the soil and the phosphate fertilizer also had a strong influence on the P concentration in the potato plants (Table 2, Fig. 2e, f). In soils with higher P availability, the phosphate fertilization had smaller effects on the $\mathrm{P}$ concentrations in the tubers and the rest of the plant than in soils with lower $\mathrm{P}$ availability, supporting the finding that very high $\mathrm{P}$ availability does not lead to increased $\mathrm{P}$ uptake and/or transport to the aboveground components of potato plants (Fernandes and Soratto 2012). However, in the soil with low $\mathrm{P}$ availability, the increase in the application of this nutrient increased the $\mathrm{P}$ concentrations in the plant, similar to the observations reported by Fernandes et al. (2015), Soratto et al. (2015), and Soratto and Fernandes (2016).

The cultivar Mondial took up the highest amount of P because of its greater DM production (Table 2). Sun et al. (2015) also reported that in potato plants fertilized with $\mathrm{P}$, the highest uptake of this nutrient resulted from high plant DM yield because the increase in the $\mathrm{P}$ concentration of different plant organs was not significant. However, Fernandes et al. (2014) found that the cultivar Mondial had the highest P uptake capacity, especially under P-sufficient conditions, due to its balance between morphological (medium length and surface area) and physiological [high maximum influx at high concentrations $\left(I_{\max }\right)$ and net $\mathrm{P}$ influx values] root characteristics, which may also have favoured the greatest $\mathrm{P}$ uptake from the soil for this cultivar in our study. The cultivars Agata and Atlantic had low DM production for the whole plant, and their P 
uptake rates were between 15 and $23 \%$ lower than those of the cultivar Mondial. This lower P uptake was partly attributed to their root systems by Fernandes et al. (2014), which were less developed than those of the cultivar Mondial, with shorter root lengths and smaller root surface areas, i.e. features that are related to the amounts of $\mathrm{P}$ taken up by plants, especially under conditions of low $\mathrm{P}$ availability. Regardless of the initial $\mathrm{P}$ availability, the $\mathrm{P}$ uptake by potato crops increased with increase in $\mathrm{P}$ application rates only up to $500 \mathrm{~kg} \mathrm{P}_{2} \mathrm{O}_{5}$ per hectare, which shows that even in P-deficient soils, the application of $\mathrm{P}$ at very high rates had no effect on plant growth and $\mathrm{P}$ uptake (Fig. $2 \mathrm{~g}$ ). This is consistent with our earlier experiments where plants were grown in nutrient solutions, in which the supply of $\mathrm{P}$ at excessive rates did not increase DM production or P accumulation in the shoots of the cultivar Agata (Fernandes and Soratto 2012). However, in the P-deficient soil, the increase in $\mathrm{P}$ uptake due to phosphate fertilization was 1.6-fold higher than in the other soils, although the maximum amounts of $\mathrm{P}$ taken up were smaller because of the lower DM production of the plants (Fig. 2d, g).

Our results show that the higher FPR in the soil with low P availability was a result of the greater increase in DM production and $\mathrm{P}$ uptake by the plants, especially at lower P application rates (Fig. 2, Table 3). The cultivar Mondial had the highest FPR, which was clearly related to its greater DM production and P uptake. Similar results have been observed in studies conducted in a field production environment (Fernandes et al. 2010, 2011b) and in a highly controlled greenhouse experiment (Soratto et al. 2015). As diffusion accounts for more than $95 \%$ of the P transferred from soil to roots (Liu et al. 2015), cultivars that have root systems with greater length and surface area, such as Mondial (Fernandes et al. 2014), can take up more P from the soil (White et al. 2005).

Mondial, Agata, and Asterix were the cultivars with the highest number of tubers per plant, and the cultivar Mondial also had a high number of larger tubers and tubers with a greater mean weight than the other cultivars (Table 4). Similar results have been reported for Mondial by other authors (Fernandes et al. 2011a; Fernandes and Soratto 2016). In the soil with low $P$ availability, $P$ application resulted in an approximate ninefold increase in the number of tubers with a diameter larger than $45 \mathrm{~mm}$; this relative increase was higher than that in the other soils (Fig. 3b). This confirms that in P-responsive soils, tuber numbers per plant are frequently increased by addition of $\mathrm{P}$ (Rosen and Bierman 2008; Rosen et al. 2014; Fernandes and Soratto 2016). The increase in the number of tubers per plant occurred until rates between 125 and $250 \mathrm{~kg} \mathrm{P}_{2} \mathrm{O}_{5}$ per hectare, but the tuber mean weight increased up to $500 \mathrm{~kg}$ ha $\mathrm{P}_{2} \mathrm{O}_{5}$ per hectare, demonstrating that small $\mathrm{P}$ amounts are sufficient to increase the number of tubers formed, but the production of larger tubers requires the use of higher $\mathrm{P}$ application rates (Fig. 3). Dubetz and Bole (1975) also observed an increase in the tuber mean weight up to $\mathrm{P}$ application rates that were higher than those that resulted in the maximum number of tubers per plant. In the experiments fertilized with $\mathrm{P}$, the total number of tubers per plant was similar for all conditions of initial $\mathrm{P}$ availability, but in the most P-fertile soils, there was a higher number of tubers with a diameter larger than $45 \mathrm{~mm}$ and the tuber weight was higher (Fig. 3). However, we must consider that the differences between the experiments may have due to not only differences in the $\mathrm{P}$ availability in the soil but also other factors, especially weather conditions (Fig. 1).

The total tuber yield and the yield of tubers with a diameter larger than $45 \mathrm{~mm}$ were highest in the cultivar Mondial, and this cultivar presented the highest DM production, P uptake, and FPR (Tables 2, 3, 4). Sandaña and Kalazich (2015) attributed tuber yield 
responses to $\mathrm{P}$ principally to changes in the total biomass of the potato plant. The tuber yield, DM production, and $\mathrm{P}$ uptake were not significantly affected by the cultivar $\times \mathrm{P}$ application rate interaction, which means it is not necessary to tailor phosphate fertilizer recommendations for individual cultivars because they respond similarly to the same rates of $\mathrm{P}$ application under field conditions (Tables 2, 4, Fig. 4). However, potato cultivars for soils with high P-fixing capacity should have considerable tolerance to low availability of this nutrient in the soil to improve APUE (Sandaña and Kalazich 2015). The increases in the total tuber yield, relative tuber yield, and yield of tubers with a diameter larger than $45 \mathrm{~mm}$ occurred up to 500,250 , and $125 \mathrm{~kg} \mathrm{P}_{2} \mathrm{O}_{5}$ per hectare in the soils with low, medium, and high $\mathrm{P}$ availability respectively, indicating that potatoes are highly responsive to higher levels of $\mathrm{P}$ fertilization only when grown in soils with low $\mathrm{P}$ availability, but some phosphate should still be applied even in soil with high initial P availability (Fig. 4a-c). Boock and Freire (1960) suggested applying 100$120 \mathrm{~kg} \mathrm{P}_{2} \mathrm{O}_{5}$ per hectare in the planting furrow for potato crops grown in soils that had previously been cultivated with crops that received P fertilization. According to Rosen et al. (2014), research conducted in some regions of North America indicated that potato crops respond to low rates of $\mathrm{P}$ applied to soils with high and very high $\mathrm{P}$ availability.

Our results demonstrate that the use of high rates of $\mathrm{P}$ applied to soil with high $\mathrm{P}$ availability does not increase the tuber yield (Fig. 4a-c), although the potato crops showed low P uptake in soil deficient in this nutrient (Fig. 2), similarly to what was reported by Pursglove and Sanders (1981) and Dechassa et al. (2003). However, in Brazil it is common for farmers to use $\mathrm{P}$ application rates higher than $600 \mathrm{~kg} \mathrm{P}_{2} \mathrm{O}_{5}$ per hectare (Sangoi and Kruse 1994; Fernandes et al. 2011b), even though several studies have shown no or only a slight increase in potato tuber yield in response to high rates of P applied to soils with high P availability (Rykbost et al. 1993; Hochmuth et al. 2002; Ali et al. 2004; Rosen and Bierman 2008; Luz et al. 2013; Rosen et al. 2014; Fernandes and Soratto 2016). According to Rosen et al. (2014), when an increase in potato tuber yield in response to $\mathrm{P}$ application occurs in soil with medium or high $\mathrm{P}$ availability, the top yields are generally achieved at a rate lower than $200 \mathrm{~kg} \mathrm{P}_{2} \mathrm{O}_{5}$ per hectare. The maximum $\mathrm{P}$ rates recommended for potatoes grown in soils with medium and high $\mathrm{P}$ availability are lower than these quantities (Lorenzi et al. 1997; Fontes 1999). Although the application of as little as $125 \mathrm{~kg} \mathrm{P}_{2} \mathrm{O}_{5}$ per hectare to the soil with low $\mathrm{P}$ availability increased the $\mathrm{P}$ concentration in the leaves into the adequate range reported by Lorenzi et al. (1997) (2.5-5.0 $\mathrm{g} \mathrm{kg}^{-1}$; Fig. 2a), the tuber yield continued to increase up to an application rate of $500 \mathrm{~kg} \mathrm{P}_{2} \mathrm{O}_{5}$ per hectare (Fig. $4 \mathrm{a}-\mathrm{c}$ ). Furthermore, in the soils with medium and high initial $\mathrm{P}$ availabilities, the potato tuber yields were increased by application of $\mathrm{P}$ fertilizer despite the leaf $\mathrm{P}$ concentrations all being higher than the minimum critical level (2.5 g P per kilogram) suggested by Lorenzi et al. (1997). This indicates that this minimum critical level may not be suitable for all situations.

The higher APUE of the potatoes grown in the soil with lower initial P availability was related to a greater crop response to the application of P (Fig. 4a, b, d). Although the tuber yields of the different cultivars increased up to the same $\mathrm{P}$ application rate in each of the three soils, the cultivar Mondial had a higher APUE than the other cultivars, especially at the lower rates of $\mathrm{P}$ application, which was the result of its higher tuber yield (Tables 3, 4). In a highly controlled greenhouse experiment with these same cultivars, the cultivar Mondial was the only efficient cultivar that responded to applied 
P in terms of fresh tuber yield (Soratto et al. 2015), and was one of the cultivars that exhibited a balance between the morphological and physiological characteristics, i.e. had medium root length and surface area and high $I_{\max }$ and net $\mathrm{P}$ influx values, which favour P uptake (Fernandes et al. 2014). Although these characteristics contributed to its higher tuber yield in the field and APUE with the lowest P application rates (Tables 3, 4), they did not alter the response of the cultivar Mondial to P application, when compared with the other cultivars (Table 4, Fig. 4a, b).

Although the cultivar Mondial had a lower P concentration in the tubers, this cultivar removed larger amounts of $\mathrm{P}$ than the other cultivars because of its high DM production of tubers and its high tuber yield (Tables 2, 4). The cultivars Agata and Atlantic removed less $\mathrm{P}$ than the other cultivars, mainly because of their lower tuber DM production (Tables 2, 4). These results demonstrate that the removal of $\mathrm{P}$ is more strongly related to the DM production of the tubers and the $\mathrm{P}$ concentration in the tubers than to the fresh tuber yield, e.g. the cultivar Agata had an intermediate fresh tuber yield and low P removal. Fernandes et al. (2011b) also observed that the removal of nutrients, including P, was not directly related to the fresh tuber yield. According to Sun et al. (2015), the higher amounts of $P$ accumulated by potato plants fertilized with this nutrient were closely related to the DM yield of the plants because the phosphate fertilizer did not cause a significant increase in the $\mathrm{P}$ concentration of the plant tissues.

Although there were differences among the cultivars with respect to the $\mathrm{P}$ concentration in the tubers, the removal of $\mathrm{P}$ by the cultivars was similar for a specific $\mathrm{P}$ rate, i.e. the cultivar $\times \mathrm{P}$ application rate interaction was not significant (Table 4). The removal of $\mathrm{P}$ increased with the rates of phosphate fertilizer applied because of increases in the $\mathrm{P}$ concentration in the tubers and the DM production of the tubers (Figs. 2b, 4e, f). Higher P removal was observed under conditions of higher initial $\mathrm{P}$ availability in the soil, and more significant removal of $\mathrm{P}$ occurred in the soil with medium $\mathrm{P}$ availability, where the $\mathrm{P}$ concentrations were high (Fig. 4e, $\mathrm{f}$ ). The average $\mathrm{P}$ removal was $10,13.7$, and $11.4 \mathrm{~kg} \mathrm{ha}^{-1}$ in the soils with low, medium, and high initial $\mathrm{P}$ availability respectively. Fernandes et al. (2011b) conducted a study with these same cultivars and obtained $\mathrm{P}$ removal rates ranging from 10 to $15 \mathrm{~kg} \mathrm{ha}^{-1}$, i.e. similar to those obtained in this study.

\section{Conclusion}

In soils with low, medium, and high $\mathrm{P}$ availabilities, the tuber yields of all potato cultivars increased similarly with increase in $\mathrm{P}$ fertilizer rate up to the respective rates of 500,250 , and $125 \mathrm{~kg} \mathrm{P}_{2} \mathrm{O}_{5}$ per hectare applied in the planting furrow, despite the leaf $\mathrm{P}$ concentrations being lower than the minimum critical level of $2.5 \mathrm{~g} \mathrm{~kg}^{-1}$ only in the absence of $\mathrm{P}$ fertilizer application in the soil with low $\mathrm{P}$ availability. The response of the potato crop to phosphate fertilizer applied to soil with low $\mathrm{P}$ availability was greater than in the more P-fertile soils. Under the condition of high $\mathrm{P}$ availability in the soil, application of $\mathrm{P}_{2} \mathrm{O}_{5}$ at only $125 \mathrm{~kg} \mathrm{ha}^{-1}$ was sufficient to achieve the maximum tuber yield. The cultivar Mondial had the highest tuber yield as well as the FPR and APUE (especially at lower $\mathrm{P}$ application rates) compared with the other cultivars studied. However, all potato cultivars responded to the same $\mathrm{P}$ application rate at a specific initial soil $\mathrm{P}$ availability. Our results suggest that the adjustment of phosphate fertilizer 
recommendations should be based on soil $\mathrm{P}$ availability, and that it is not necessary to use different criteria to evaluate the P-nutritional status for individual potato cultivars.

Acknowledgments We thank the São Paulo Research Foundation (FAPESP) for supporting this research and for providing a scholarship to Adalton M. Fernandes (Proc. 2010/04987-6). We are grateful to the National Council for Scientific and Technological Development $(\mathrm{CNPq})$ for supporting this research (Proc. 480757/2010-0) and for providing an award for excellence in research to Rogério P. Soratto. We also thank the potato grower (Grupo Ioshida), which provided the areas for this investigation, and the Brazilian Potato Association (ABBA), which provided the seed tubers.

\section{References}

ABBA - Associação Brasileira da Batata (2010) Variedades. Rev Batata Show 10:1-4

Ali H, Anjum MA (2004) Aerial growth and dry matter production of potato (Solanum tuberosum L.) cv. Desiree in relation to phosphorus application. Int J Agric Biol 6:458-461

Ali H, Anjum MA, Randhawa SA (2004) Influence of phosphorus on yield potential of potato (Solanum tuberosum L.) crops. Int J Agric Biol 6:165-167

Alvarez-Sánchez E, Etchevers JD, Ortiz J, Núñez R, Volke V, Tijerina L, Martínez A (1999) Biomass production and phosphorus accumulation of potato as affected by phosphorus nutrition. J Plant Nutr 22:205-217. doi:10.1080/01904169909365618

Barben SA, Hopkins BG, Jolley VD, Webb BL, Nichols BA (2010) Phosphorus and zinc interactions in chelator-buffered solution grown russet Burbank potato. J Plant Nutr 33:587-601. doi:10.1080 /01904160903506308

Boock OJ, Freire ES (1960) Adubação da batatinha - experiências com doses crescentes de fósforo. Bragantia 19:369-391. doi:10.1590/S0006-87051960000100025

Chien SH, Sikora FJ, Gilkes RJ, McLaughlin MJ (2012) Comparing of the difference and balance methods to calculate percent recovery of fertilizer phosphorus applied to soils: a critical discussion. Nutr Cycl Agroecosyst 92:1-8. doi:10.1007/s10705-011-9467-8

Dechassa N, Schenk MK, Claassen N, Steingrobe B (2003) Phosphorus efficiency of cabbage (Brassica oleraceae L. var. capitata), carrot (Daucus carota L.), and potato (Solanum tuberosum L.). Plant Soil 250: 215-224

Dubetz S, Bole JB (1975) Effect of nitrogen, phosphorus, and potassium fertilizers on yield components and specific gravity of potatoes. Am Potato J 52:399-405. doi:10.1007/BF02852794

FAOSTAT (2016) Production: potatoes. Food and Agriculture Organization of the United Nations, Rome. Available via http://faostat.fao.org/site/567/default.aspx\#ancor. Accessed 12 Feb 2016

Fernandes AM, Soratto RP (2012) Nutrition, dry matter accumulation and partitioning and phosphorus use efficiency of potato grown at different phosphorus levels in nutrient solution. Rev Bras Cienc Solo 36: 1528-1537. doi:10.1590/S0100-06832012000500017

Fernandes AM, Soratto RP (2016) Phosphorus fertilizer rate for fresh market potato cultivars grown in tropical soil with low phosphorus availability. Am J Potato Res 93:404 414. doi:10.1007/s12230-016-9515-7

Fernandes AM, Soratto RP, Silva BL, Souza-Schlick GD (2010) Crescimento, acúmulo e distribuição de matéria seca em cultivares de batata na safra de inverno. Pesq Agropec Bras 45:826-835. doi:10.1590 /S0100-204X2010000800008

Fernandes AM, Soratto RP, Evangelista RM, Silva BL, Souza-Schlick GD (2011a) Produtividade e esverdeamento pós-colheita de tubérculos de cultivares de batata produzidos na safra de inverno. Rev Ciênc Agron 42:502-508. doi:10.1590/S1806-66902011000200033

Fernandes AM, Soratto RP, Silva BL (2011b) Extração e exportação de nutrientes em cultivares de batata: I Macronutrientes. Rev Bras Cienc Solo 35:2039-2056. doi:10.1590/S0100-06832011000600020

Fernandes AM, Soratto RP, Gonsales JR (2014) Root morphology and phosphorus uptake by potato cultivars grown under deficient and sufficient phosphorus supply. Sci Hortic 180:190-198. doi:10.1016/j. scienta.2014.10.035

Fernandes AM, Soratto RP, Pilon C (2015) Soil phosphorus increases dry matter and nutrient accumulation and allocation in potato cultivars. Am J Potato Res 92:117-127. doi:10.1007/s12230-014-9422-8

Ferreira DF (2011) Sisvar: a computer statistical analysis system. Cienc Agrotecnol 35:1039-1042 
Fontes PCR (1999) Batata. In: Ribeiro AC, Guimarães PTG, Alvarez VVH (eds) Recomendações para o uso de corretivos e fertilizantes em Minas Gerais - $5^{\text {a }}$ aproximação. CFSEMG, Viçosa, p 179

Fontes PCR, Rocha FAT, Martinez HEP (1997) Produção de máxima eficiência econômica da batata em função da adubação fosfatada. Hortic Bras 15:104-107

Freeman KL, Franz PR, Jong RW (1998) Effect of phosphorus on the yield, quality and petiolar phosphorus concentrations of potatoes (cv. Russet Burbank and Kennebec) grown in the krasnozem and duplex soils of Victoria. Aust. J Exp Agric 38:83-93

Hochmuth G, Weingartner P, Hutchinson C, Tilton A, Jesseman D (2002) Potato yield and tuber quality did not respond to phosphorus fertilization of soil testing high in phosphorus content. Hortechnology 12:420 422

Hopkins BG, Horneck DA, MacGuidwin AE (2014) Improving phosphorus use efficiency through potato rhizosphere modification and extension. Am J Potato Res 91:161-174. doi:10.1007/s12230-014-9370-3

Liu C, Rubaek GH, Liu F, Andersen MN (2015) Effect of partial root zone drying and deficit irrigation on nitrogen and phosphorus uptake in potato. Agric Water Manag 159:66-76

Lorenzi JO, Miranda Filho HS, van Raij B (1997) Raízes e tubérculos. In: van Raij B, Cantarella H, Quaggio JA, Furlani AMC (eds) Recomendações de adubação e calagem para o Estado de São Paulo, 2nd edn. Instituto Agronômico, Campinas, pp 221-229

Luz JMQ, Queiroz AA, Borges M, Oliveira RC, Leite SS, Cardoso RR (2013) Influence of phosphate fertilization on phosphorus levels in foliage and tuber yield of the potato cv. Agata. Sem Cienc Agric 34: 649-656. doi:10.5433/1679-0359.2013v34n2p649

Malavolta E, Vitti GC, Oliveira SA (1997) Avaliação do estado nutricional das plantas: princípios e aplicações, 2nd edn. Potafos, Piracicaba

Pursglove JD, Sanders FE (1981) The growth and phosphorus economy of the early potato (Solanum tuberosum). Commun Soil Sci Plant Anal 12:1105-1121. doi: 10.1080/00103628109367222

Rosen CJ, Bierman PM (2008) Potato yield and tuber set as affected by phosphorus fertilization. Am J Potato Res 85:110-120. doi:10.1007/s12230-008-9001-y

Rosen CJ, Kelling KA, Stark JC, Porter GA (2014) Optimizing phosphorus fertilizer management in potato production. Am J Potato Res 91:145-160. doi:10.1007/s12230-014-9371-2

Ruark MD, Kelling KA, Good LW (2014) Environmental concerns of phosphorus management in potato production. Am J Potato Res 91:132-144. doi:10.1007/s12230-014-9372-1

Rykbost KA, Christensen NW, Maxwell J (1993) Fertilization of Russet Burbank in short-season environment. Am Potato J 70:699-710. doi:10.1007/BF02848676

Sánches PA, Salinas JG (1981) Low-input technology for managing oxisols and ultisols in tropical America. Adv Agron 34:279-406. doi:10.1016/S0065-2113(08)60889-5

Sandaña P, Kalazich J (2015) Ecophysiological determinants of tuber yield as affected by potato genotype and phosphorus availability. Field Crop Res 180:21-28. doi:10.1016/j.fcr.2015.05.005

Sangoi L, Kruse ND (1994) Doses crescentes de nitrogênio, fósforo e potássio e características agronômicas da batata em dois níveis de pH. Pesq Agrop Bras 29:1331-1343

Soratto RP, Fernandes AM (2016) Phosphorus effects on biomass accumulation and nutrient uptake and removal in two potato cultivars. Agron J 108:1225-1236. doi:10.2134/agronj2015.0333

Soratto RP, Pilon C, Fernandes AM, Moreno LA (2015) Phosphorus uptake, use efficiency, and response of potato cultivars to phosphorus levels. Potato Res 58:121-134. doi:10.1007/s11540-015-9290-8

Sun Y, Cui X, Liu F (2015) Effect of irrigation regimes and phosphorus rates on water and phosphorus use efficiencies in potato. Sci Hortic 190:64-69. doi:10.1016/j.scienta.2015.04.017

Thornton MK, Novy RG, Stark JC (2014) Improving phosphorus use efficiency in the future. Am J Potato Res 91:175-179. doi:10.1007/s12230-014-9369-9

Valladares GS, Pereira MG, Anjos LHC (2003) Adsorção de fósforo em solos de argila de atividade baixa. Bragantia 62:111-118. doi:10.1590/S0006-87052003000100014

van Raij B, Quaggio JA, Cantarella H, Abreu CA (1997) Interpretação de resultados de análise de solo. In: van Raij B, Cantarella H, Quaggio JA, Furlani AMC (eds) Recomendações de adubação e calagem para o Estado de São Paulo, 2nd edn. Instituto Agronômico, Campinas, pp 8-13

van Raij B, Andrade JC, Cantarella H, Quaggio JA (2001) Análise química para avaliação da fertilidade de solos tropicais. Instituto Agronômico, Campinas

White PJ, Broadley MR, Hammond JP, Thompson AJ (2005) Optimising the potato root system for phosphorus and water acquisition in low-input growing systems. Asp Appl Biol 73:111-118

Yorinori GT (2003) Curva de crescimento e acúmulo de nutrientes pela cultura da batata cv. 'Atlantic'. Dissertation, University of São Paulo 